\title{
VISION OF THE IDEAL PRISON DESIGN ACCORDING TO THE HUMAN RIGHTS CONSIDERATIONS
}

Radwa Emam Soliman 1, Zeinab El-Razaz 2, Mohammed Saif EL-Nasr 3 1 Assistant lecturer, 2 Professor, 3 Assistant Professor Architecture Dep., Faculty of Engineering-Mattaria, Helwan University

\begin{abstract}
The current research aims to Analysis and studies global prison buildings (West Kimberley Regional Prison-Australia 2012) according to the Human Rights $\mathrm{n}$ standard requirements additionally, introducing new types of prisons that proved successful experiences in the advanced countries. This research concluded that:

- There are specific design criteria for prison buildings on which the needs of the functional spaces are based, there is a program of functional needs, taking into account the parameters that define the architectural design of the quality of those buildings (such as future allocations - choice of execution sites - the quality of prisoners - investment aspect of those buildings

- The design provided with modern design considerations applied worldwide, which can be relied upon to reach an integrated program that includes locating the implementation of these types of buildings and determining the functional requirements of these buildings.
\end{abstract}

Keywords: Vision - ideal prison design - Human Rights Considerations 


\section{1 - Introduction:}

The current research aims to study the design of the building of one of the international prisons designed according to the human rights standards mentioned in the international agreements, to benefit from it in deriving an ideal design vision for the prison building.

Greece has changed the situation to allow cells, from dark places underground to rooms with high walls of wood, criminals, serials of feet and hands, and their families to visit them from time to time. While in the ancient Roman Empire, officials mastered how to punish the perpetrators. They put the cells under the ground, tied their hands and locked them in very narrow corridors, causing them to suffocate for an indefinite period, and then used as wrestlers. $]^{1}[$

The crime was a social and human reality. Without regard to moral responsibility, the social reaction should be limited to precautionary measures without conventional sanctions. Thus, the implementation of precautionary measures representing criminal punishment must aim at addressing the factors that led to the crime, whether linked to the offender or other external factors $]^{2}[$. So, American Prisons is a unique institution with a history of almost 200 years of inhumanity, followed by good attempts at reform but short-term $]^{3}[$.

The objective of the prison is protecting the community from offenders who cannot serve their sentence within the community due to the severity of their crime or nature and providing a safe and dignified system to help rehabilitate criminals so that they can lead meaningful lives while in prison and upon release. For any long-term enterprise, decisions taken at the front of the design process will have far-reaching implications throughout the operational life of the prison facility, with a significant impact on its function and the ability of the prison administration to conduct a safe operation. , A safe and respectable system that meets international standards $]^{4}[$

It is also important to note that each prison or renovation project is unique and presents its challenges and opportunities - a "one size fits all" approach is not appropriate since the design or renewal of one prison model cannot be transferred to different locations. Similarly, when considering basic compliance or best practices in prison design and renovation, caution should be exercised in deciding whether specific measures could be successfully included in the preparation of the proposed project. $]^{5}[$

\subsection{Research problem:}

Many countries design the prison building on the basis that it is a place for punishment - and therefore this building is designed not according to any humanitarian considerations, and there are other models of prisons that were designed according to those considerations contained in many agreements, and this study aims at some models that were designed according to considerations 
Contained in human rights agreements in general and the rights of the prisoner in particular.

\subsection{The objective of the research:}

Analysis and study global examples of prison buildings according to the Human Rights $n$ standard requirements .Additionally, introducing new types of Prisons which proved successful experiences in the advanced Countries

\subsection{Hypothesis:}

The design of the prison building, based on the considerations contained in human rights agreements in general and the rights of the prisoner, provides the prisoner with the enjoyment of his rights within the prison building, and in the absence of these considerations, there is an absence of protection for the rights of the prisoner.

\section{Methodology:}

This research will consist of an analytical approach that will be conducted in the form of a group of activities as reviewing many types of literature and references including different types of books, periodicals, papers, internet sites for inference knowledge and concepts. With the help of the concluded results and deductions. Additionally, a deductive approach will be conducted in addition to a comparative analysis that will set up according to the use of the knowledge gained throughout the research. Through the previous presentation of the prison model (West Kimberley Prison), the researcher designed a notecard to assess the humanitarian standards and considerations contained in the human rights agreements, as it stipulated.

\section{Case Study:}

Below is a presentation of Designing prisons of West Kimberley Regional Prison-Australia 2012 following human rights standards

\subsection{Site consideration:}

Early in the design process, architects realized that potential users of the facility would come from diverse backgrounds. With over 421,000 square kilometers of dramatic landscapes, Kimberley is home to indigenous peoples from 27 traditional linguistic groups. Each language group has distinct and diverse cultural practices and spiritual ties with the country. Many people in the region still live traditional lifestyles in small, remote communities. The creation of an original "best practice" prison involves envisioning ways to meet diverse cultural and physical needs and allowing different groups to live in harmony within a confined location. 


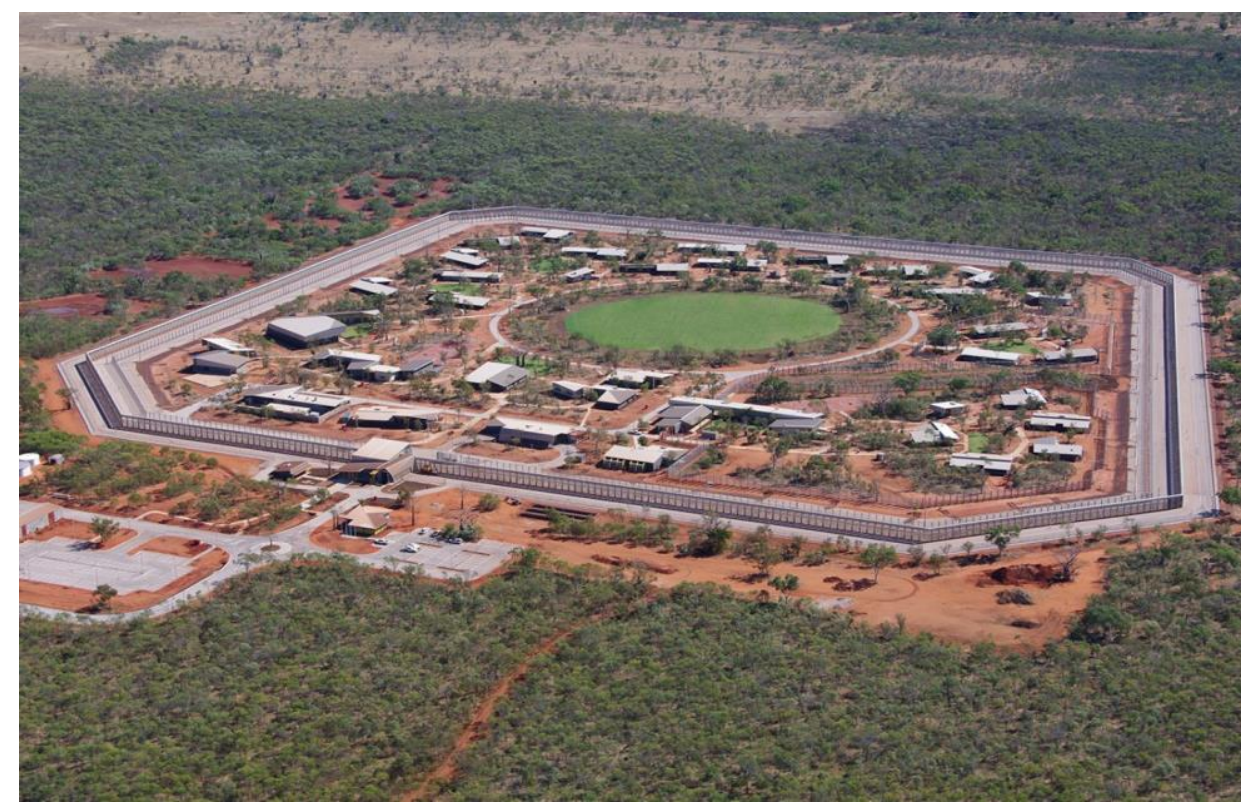

Figure (1) West Kimberley prison ${ }^{6}$

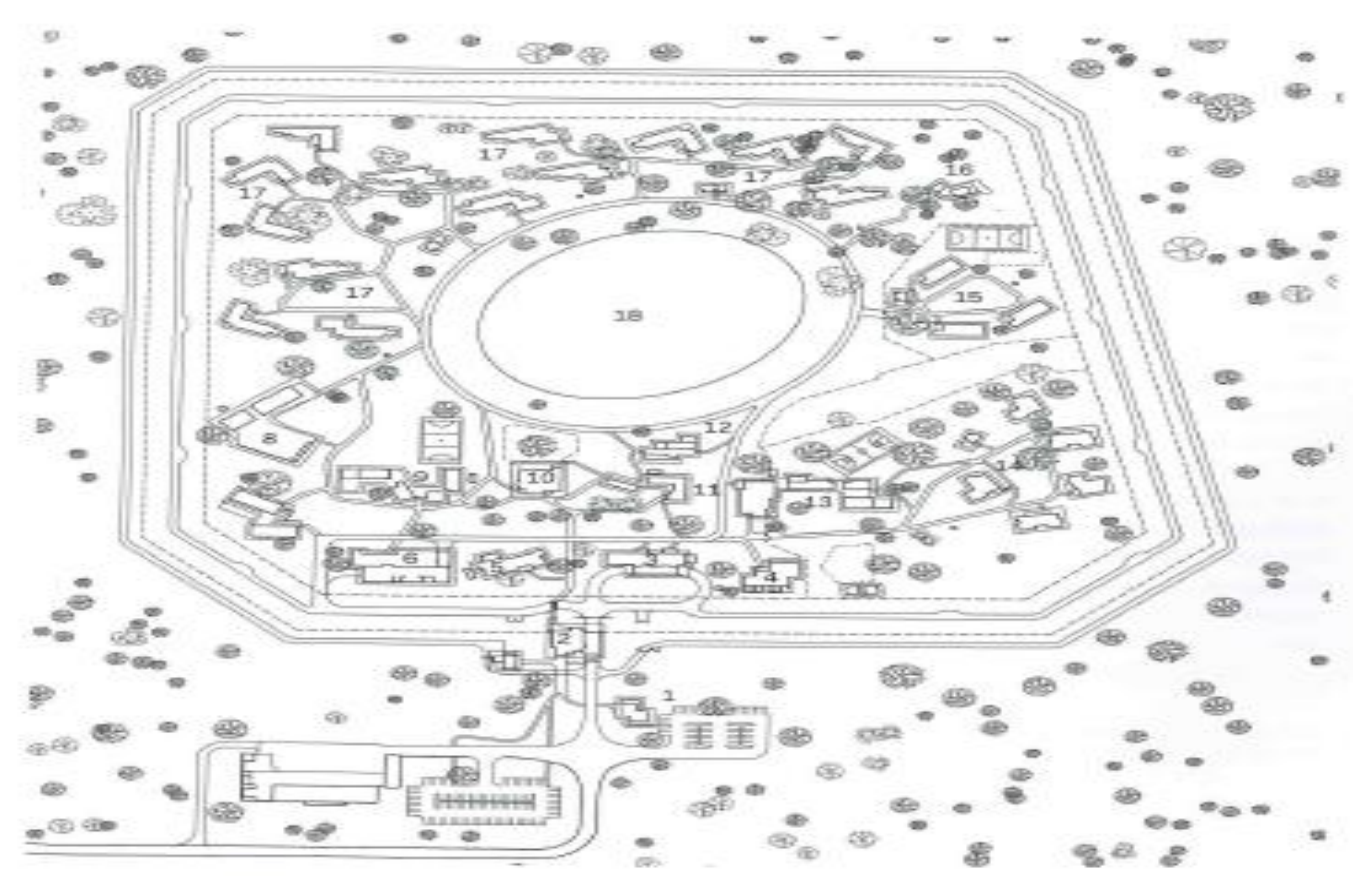

Figure 1 West Kimberley site plan] $\left.]^{7}\right]$

\subsection{Overview:}

The application of research and evidence-based experience led to a very innovative design. The $\$ 122$ million prisons are located on a 25 -hectare site of green fields outside Derby and aim to accommodate up to 150 prisoners. The design is based on the knowledge that prison accommodation must be flexible, culturally appropriate, promote human interaction, and enable indigenous prisoners to stay in touch with their relatives, land, and community. 
The West Kimberley Regional Prison consists of forty-two buildings, including 22 self-catering accommodation units within a campus master plan. Common facilities include a gate, professional and educational buildings, cultural meeting areas, program areas for the elderly, a kitchen and laundry building, prison service areas, a family visit area, a medical center, and a courtroom. $]^{8}[$

\subsection{The architectural and analytical study of the prison:}

The West Kimberley Regional Prison consists of forty-two buildings, including twenty-two self-care accommodation units laid out within a campus master plan. Shared facilities include a gatehouse, vocational and educational buildings, cultural meeting areas, elders program areas, a kitchen and laundry building, prisoner service areas, a family visiting area, a Medical Centre and a courtroom. $]^{9}[$

The building design and materials were subject to several computer simulations to ensure they could perform in extreme temperatures. All buildings are orientated to minimize solar radiation and to maximize natural cross-ventilation and are highly shaded to reduce heat loads.

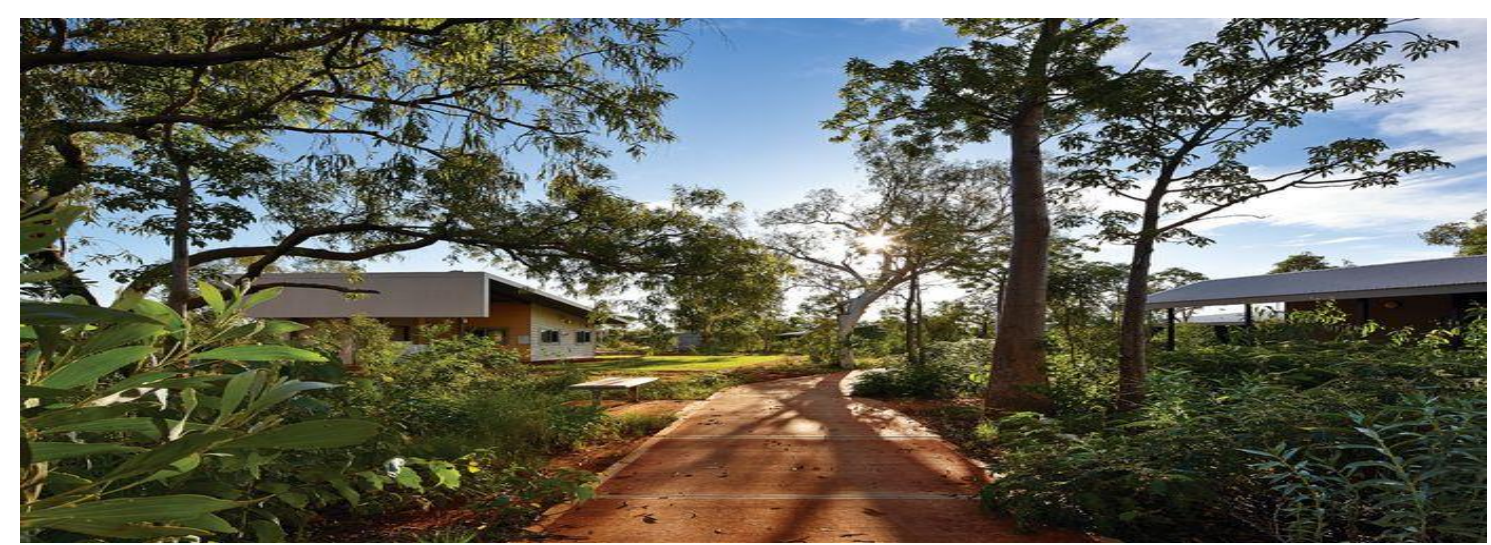

\subsection{Master planning:}

The master planning for the project took into account cultural connections to the surrounding landscape. Buildings were sited to minimize the removal of trees; several iconic bob trees have been preserved. ${ }^{10}[$ ]

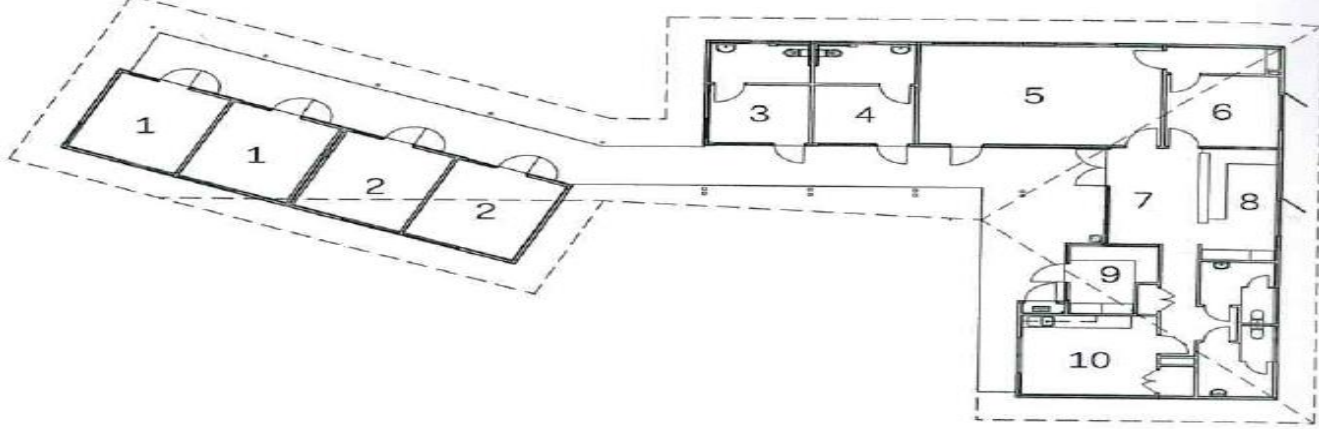

Figure (3) Court service floor plan $]^{11}[$ 


\author{
Court services key \\ 6- Agency office/interview room \\ 7- Agency office \\ 8- Male holding \\ 9- Female holding \\ 10- Case management and video court
}

1- Interview room

2- Waiting area

3- Reception

4- Officer

5- Staff amenities

\section{5. views:}

The master planning for the project took into account cultural connections to the surrounding landscape. Buildings were sited to minimize the removal of trees; several iconic bob trees have been preserved. The architects fought to reduce the number of solid barriers to allow views of the landscape within and beyond the perimeter. The colors of the landscape informed the buildings' exterior color palette, which reflects the seasonal changes of the subtropics, increasing prisoners' sense of connection to country. $]^{12}[$

\subsection{Education:}

Many of the crimes represented in prison are often related to lack of education, opportunity, and life skills, as well as substance abuse. The brief for the West Kimberley Regional Prison asked for the creation of appropriate space for the facilitation of culturally specific education and training programs and instruction in domestic skills. Its location meant it would also allow prisoners to stay close to clan and country. $]^{13}[$

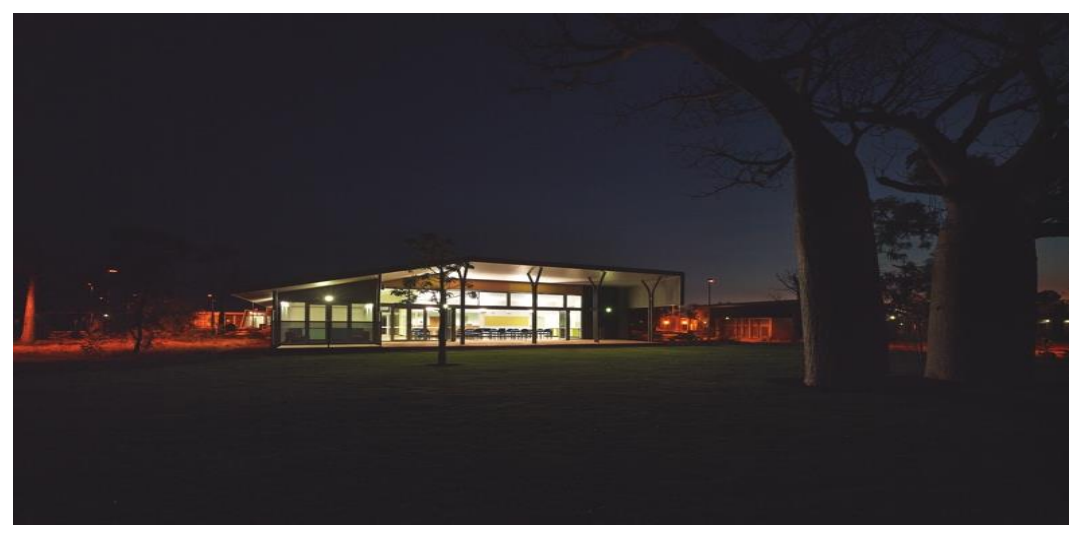

Figure (4) Building of classrooms

\subsection{Healthcare:}

Prisons provide an opportunity for the Indigenous population to access health care, something they often do not do in the outer community. The health needs of Aboriginal prisoners were carefully considered in the planning and design of the West Kimberley Regional Prison and the complex includes services not typically seen in other Australian prisons. Another point of difference is the provision of air-conditioning. Although Western Australia has extremes of temperature, mechanical cooling in the state's prisons is rare. At the West 
Kimberley Regional Prison air-conditioning allows prisoners (especially those with complex health issues) to be safely and humanely housed. $]^{14}[$

\subsection{Outside (yard):}

Through the extensive glass panels of the gatehouse, one views the service and housing buildings inside the prison, sited around an Australian Rules oval. The oval is placed centrally to encourage life aspirations among the prisoners. It creates a focus for recreational activities and provides a space where family and community can participate in prison life. $]^{15}[$

\section{The components of the prison and their areas:}

Table1: component's area

\begin{tabular}{|r|l|r|}
\hline no & Components & area \\
\hline 1. & Administration, visiting area, reception & 1458 \\
\hline 2. & Hospital & 4012 \\
\hline 3. & VIP area & 606 \\
\hline 4. & Service area & 2056 \\
\hline 5. & Housing & 20152 \\
\hline 6. & Single officer accommodation building & 1556 \\
\hline 7. & Worden accommodation & 1457 \\
\hline \multicolumn{2}{|l|}{ The tolal area of established buildings } & 31297 \\
\hline
\end{tabular}

\section{Areas}

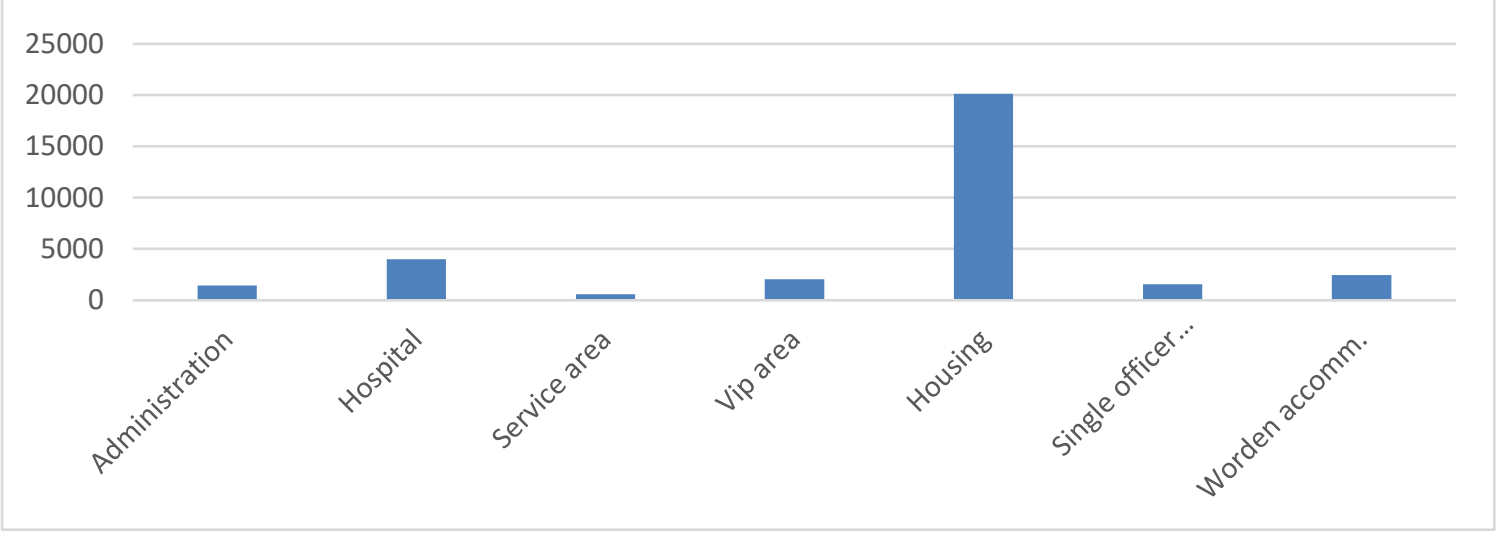


Mohammed Saif EL-Nasr/Engineering Research Journal 166 (June 2020) A18-A33

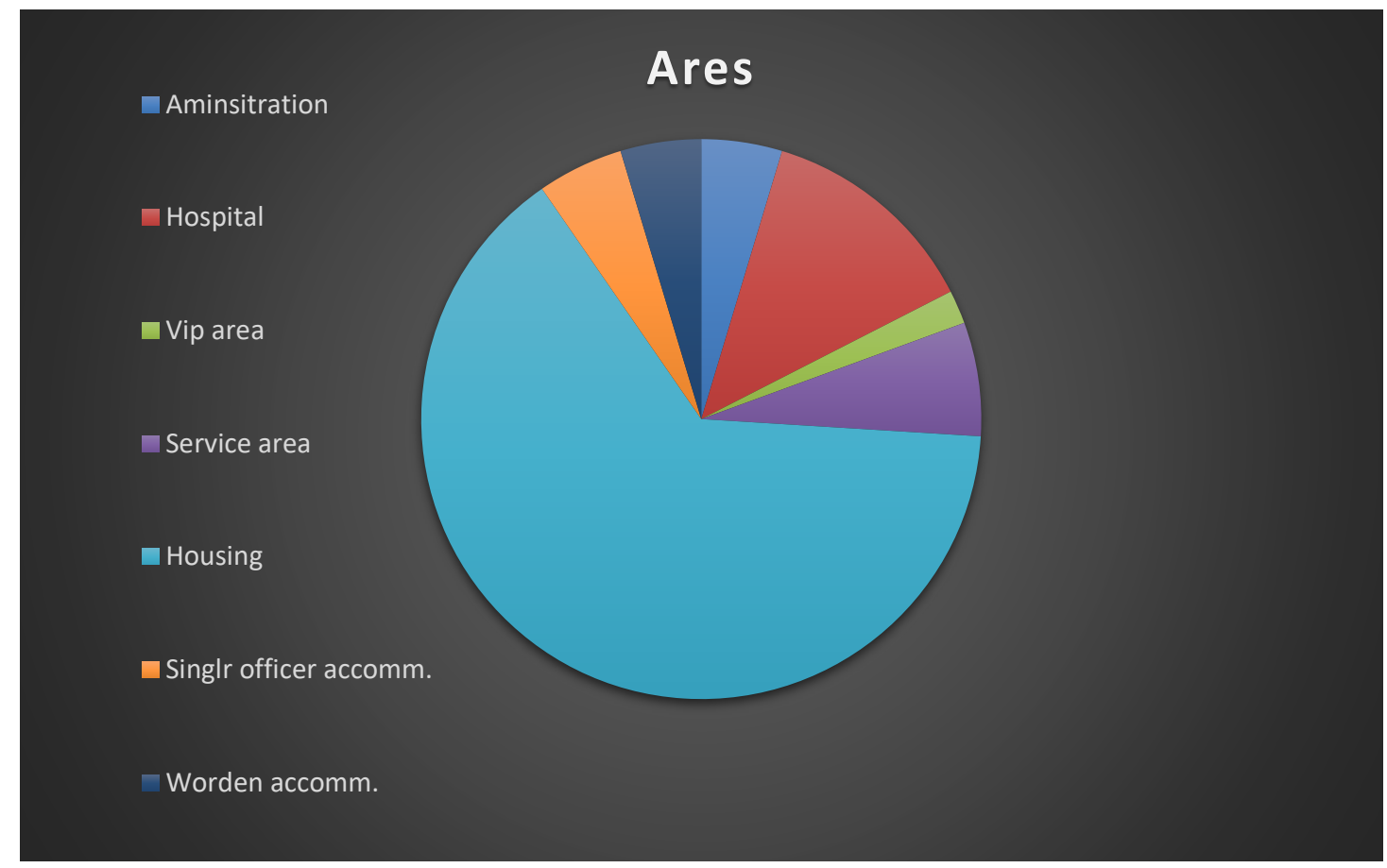

The percentage area of the prison

\section{Specified area}

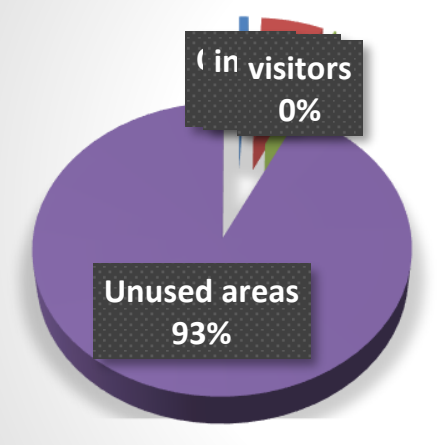

Offers

inmates

visitors

Unused areas 
Mohammed Saif EL-Nasr/Engineering Research Journal 166 (June 2020) A18-A33

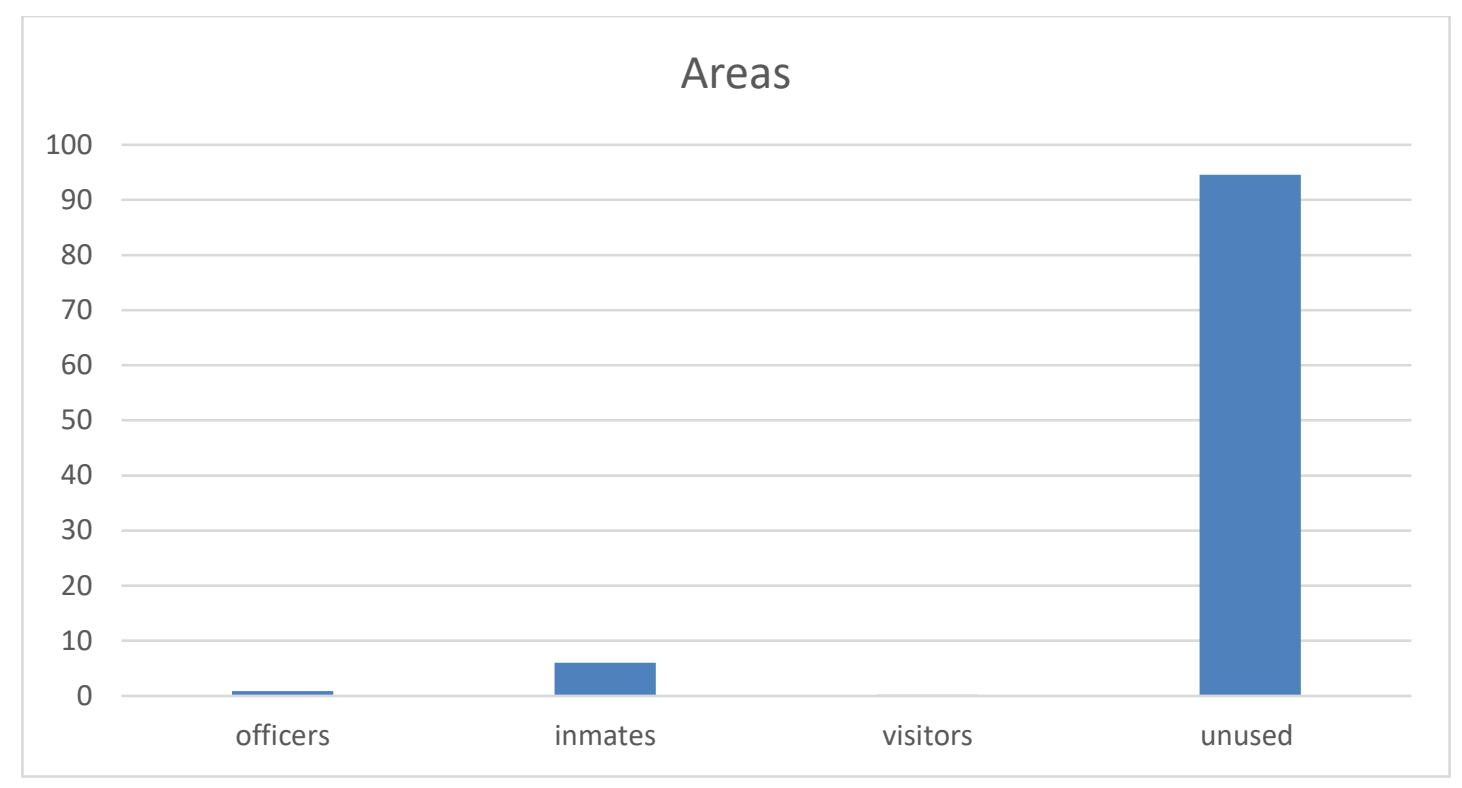

The relation between the prison's components

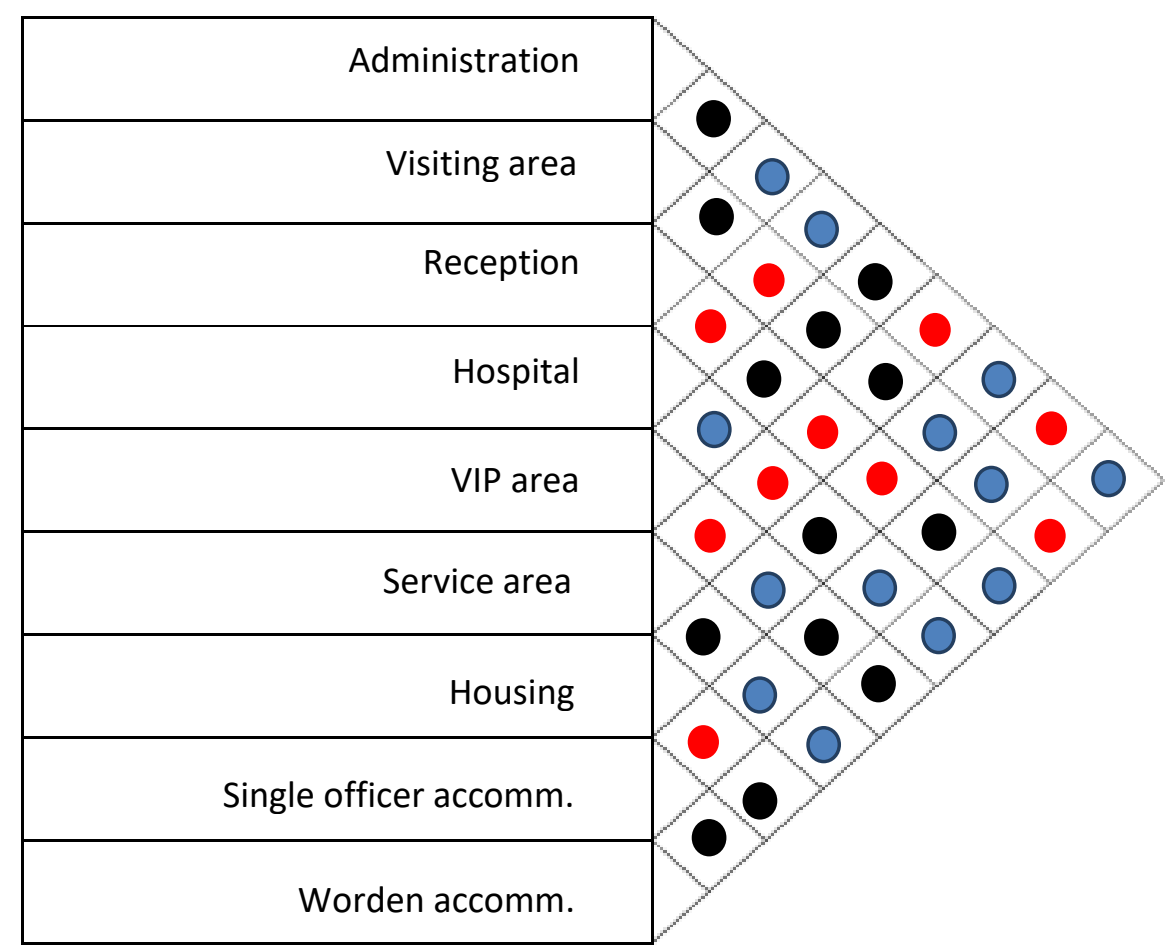

Direct relation

Semi Direct relation

No relation 


\section{Result:}

Through the previous presentation of the prison model (West Kimberley Prison), the researcher designed a notecard to assess the humanitarian standards and considerations contained in the human rights agreements, as it stipulated, the Mandela Rules declare that it is not desirable to have two prisoners in one cell, Additionally, The European Court of Human Rights has determined that "complete sensory isolation, coupled with total social isolation...constitutes a form of inhuman treatment which cannot be justified by the requirements of security or any other reason. Also, According to the Special Rapporteur of the Human Rights Council on torture and other cruel, inhuman or degrading treatment or punishment, 15 days is the uppermost limit of permissible solitary confinement, "because at that point...some of the harmful psychological effects of isolation can become irreversible. $]^{16}[$

\section{Design Criteria for West Kimberley Prison}

\begin{tabular}{|c|c|c|c|c|c|c|c|c|c|c|c|c|}
\hline \multirow{13}{*}{ 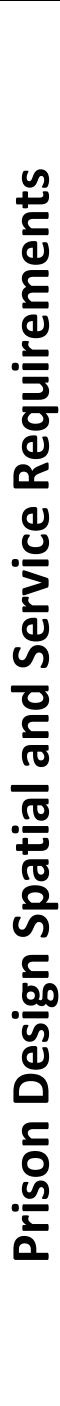 } & \multicolumn{12}{|c|}{ PRISON PROFILE } \\
\hline & & 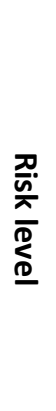 & 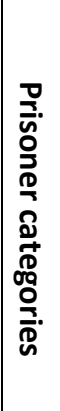 & 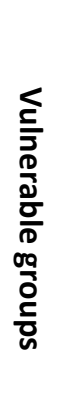 & 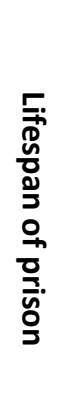 & 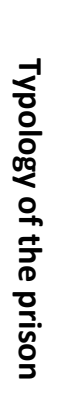 & 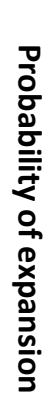 & 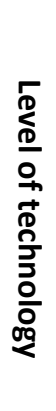 & 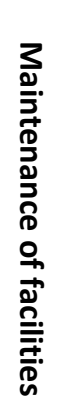 & 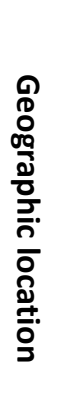 & 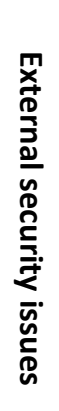 & 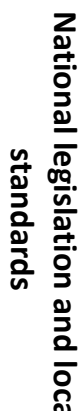 \\
\hline & Master planning & & & & & & & & & & & \\
\hline & Single $\&$ shared cells & & & & & & & & & & & \\
\hline & Dormitories & & & & & & & & & & & \\
\hline & Mother baby units & & & & & & & & & & & \\
\hline & Visits & & & & & & & & & & & \\
\hline & Dayroom & & & & & & & & & & & \\
\hline & Yard & & & & & & & & & & & \\
\hline & Classrooms & & & & & & & & & & & \\
\hline & Library & & & & & & & & & & & \\
\hline & Workshops & & & & & & & & & & & \\
\hline & Health facilities & & & & & & & & & & & \\
\hline
\end{tabular}


Mohammed Saif EL-Nasr/Engineering Research Journal 166 (June 2020) A18-

A33

\begin{tabular}{|l|l|l|l|l|l|l|l|l|l|l|l|}
\hline Kitchen areas & & & & & & & & & & & \\
\hline Mess areas & & & & & & & & & & & \\
\hline Physical Recreation & & & & & & & & & & & \\
\hline Other facilities & & & & & & & & & & & \\
\hline Main gate & & & & & & & & & & & \\
\hline Security dept. & & & & & & & & & & & \\
\hline Staff facilities & & & & & & & & & & & \\
\hline Main entrance & & & & & & & & & & & \\
\hline Central stores & & & & & & & & & & & \\
\hline Administration & & & & & & & & & & & \\
\hline
\end{tabular}

Through the presentation of the previous model, it can be said that the design of a prison building was carried out following humanitarian considerations that take into account the protection of the prisoner and his enjoyment of many of his rights mentioned in international human rights agreements.

Prison design expresses the philosophy of imprisonment and can be a tool towards rehabilitation. In addition to the specific recommendations contained in this document, development teams should attempt to design the prison facilities in a manner that considers the psychological health of the prisoner and creates a positive and mentally stimulating. 


\subsection{MASTER PLANNING CONSIDERATIONS FOR THE DESIGN OF HUMANE PRISONS:}

\section{Specifications:}

Floor area (net):

At least $5.4 \mathrm{~m}^{2}$, for single-cell accommodation (ICRC)

At least $3.4 \mathrm{~m}^{2}$ per person, for shared accommodation.

At least $2.15 \mathrm{~m}(\mathrm{ICRC})$

Distance b/w walls:

Height of the room:

At least $2.45 \mathrm{~m}$, but more may be needed in warmer climates (ICRC) At

Ventilation area:

least $4 \%$ of the net floor area (IBC)

Where infeasible, must be greater than $.1 \mathrm{~m}^{2} /$ person.

Total clear glazed window area, at least $8 \%$ of the net

Daylighting area:

Floor area(net): floor area. (IBC) Where infeasible, must be greater than $.1 \mathrm{~m}^{2} /$ person. At least $5.4 \mathrm{~m}^{2}$, for single-cell accommodation (ICRC) At least $3.4 \mathrm{~m}^{2}$ per person, for shared accommodation.

Distance b/w walls:

At least $2.15 \mathrm{~m}$ (ICRC)

Height of the room:

Ventilation area:

At least $2.45 \mathrm{~m}$, but more may be needed in warmer climates (ICRC) At least $4 \%$ of the net floor area (IBC)

Where infeasible, must be greater than. $1 \mathrm{~m}^{2} /$ person.

Daylighting area:

Total clear glazed window area, at least $8 \%$ of the net floor area. (IBC)

Where infeasible, must be greater than. $1 \mathrm{~m}^{2} /$ person.

\subsection{Prison's Housing unit's interior:}
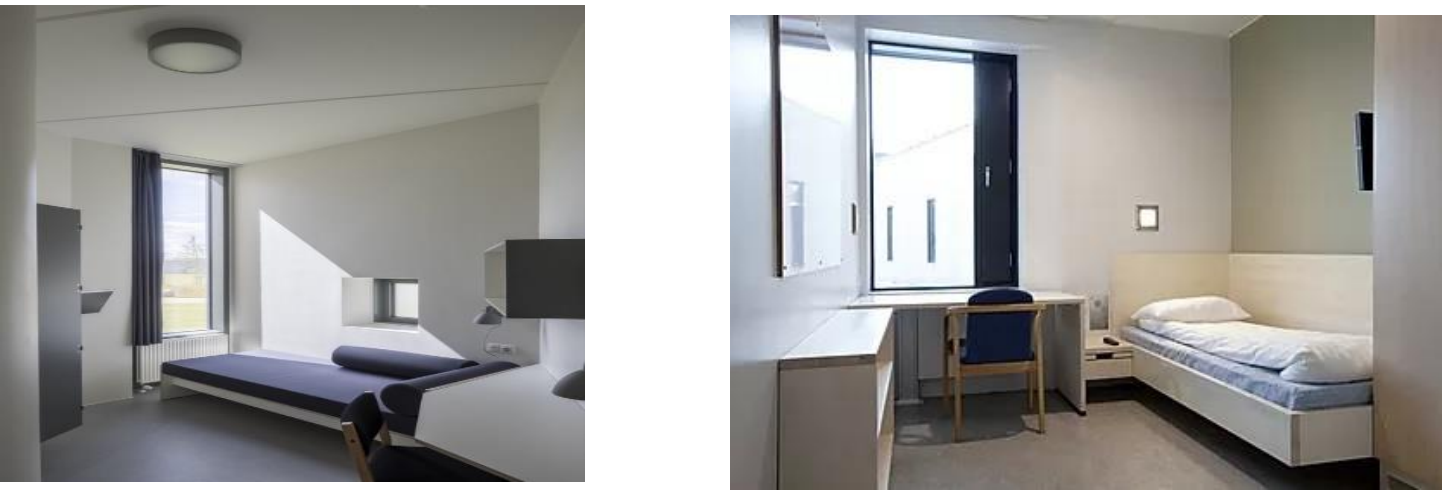
Mohammed Saif EL-Nasr/Engineering Research Journal 166 (June 2020) A18-

A33

Specifications:

Floor area (net): $\quad 3.4 \mathrm{~m}^{2}$ per person for dormitories containing single beds;

(ICRC)

$2.6 \mathrm{~m}^{2}$ per person for dormitories containing double bunk beds; and $2.3 \mathrm{~m}^{2}$ per person for dormitories containing triple bunk beds.

Height of the room:

At least $2.45 \mathrm{~m}$, but more may be needed in warmer climates or if triple bunks are used (ICRC)

Distance b/w walls:

At least $2.15 \mathrm{~m}$ (ICRC) $1.2 \mathrm{~m}$ (ICRC) $3.4 \mathrm{~m}^{2}$ per person for dormitories containing

Min. vertical space

At least $2.45 \mathrm{~m}$, but more may be needed in warmer climates (ICRC)

Between beds: Height

At least $4 \%$ of the net floor area (IBC)

Day lighting

Where infeasible, must be greater than $.1 \mathrm{~m}^{2} /$ person.

\subsection{Sanitary and bathing installations:}

Providing adequate facilities and materials to ensure that prisoners can maintain their hygiene is critical to the fulfillment of international standards, including the Mandela Rules, the Principles and Best Practices of the IACHR, and the Bangkok Rules.

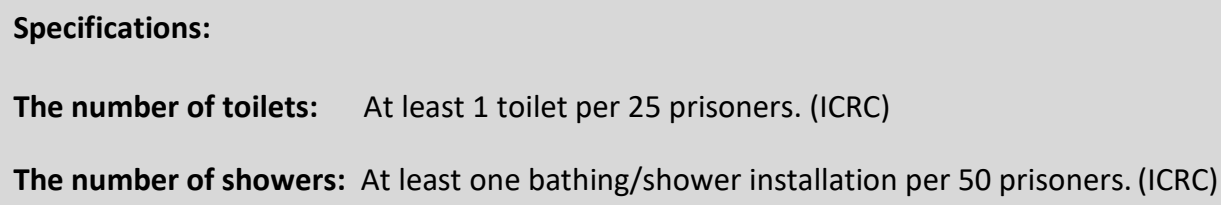

\subsection{Yard:}

According to the Mandela Rules, prisoners should be given access to at least one hour of exercise in the open air.

\section{Specifications:}

Yard area: At least $4 \mathrm{~m}^{2}$ per prisoner.

The total combined area for the yard and the dayroom is at least $8 \mathrm{~m}_{2}$ per prisoner.

\subsection{VISITS:}

The right of a prisoner to maintain contact with family members, friends, and legal representatives through regular correspondence and visits is established in the Mandela Rules and reinforced by later international 
standards, including the Body of Principles, EPRs, and the Principles and Best Practices of the IACHR, among others.

\subsection{EDUCATION:}

Education is a human right for all individuals, limited only as "demonstrably necessitated by the fact of incarceration". Additionally, it is recognized that the right to an education is "an indispensable means of realizing other human rights" and "the primary vehicle by which economically and socially marginalized adults and children can lift themselves out of poverty and obtain the means to participate fully in their communities."

\section{Specifications:}

Height of the room: Ventilation area:

At least $2.45 \mathrm{~m}$, but more may be needed in warmer climates (ICRC) At least $4 \%$ of the net floor area (IBC) where infeasible, must be greater than $.1 \mathrm{~m} 2 /$ person.

\section{Daylighting area:}

Total clear glazed window area, at least $8 \%$ of the net floor area. (IBC) Where infeasible, must be greater than $.1 \mathrm{~m} 2 /$ person.

\section{Conclusion:}

By reviewing the important definitions and different concepts contained in the research and the principles on which it was based, and through analyzing the model presented in the study, search concluded the following results:

- There are specific design criteria for prison buildings on which the needs of the functional spaces are based, there is a program of functional needs, taking into account the parameters that define the architectural design of the quality of those buildings (such as future allocations - choice of execution sites - the quality of prisoners investment aspect of those buildings

- The design provided with modern design considerations applied worldwide, which can be relied upon to reach an integrated program that includes locating the implementation of these types of buildings and determining the functional requirements of these buildings.

\section{Recommendation:}


The following are recommendations that may contribute to the dissemination and generalization of the idea of designing prisons following humanitarian considerations and human rights standards

- Setting codes and standards for the design of the prison building following human rights standards starting from the urban planning process to the architectural design of buildings and conditions that must be met as much as possible in the building.

- Connect green infrastructure and ecosystem services and provide a framework for comprehensive planning of urban green spaces as part of the prison building design

- Use a wide variety of concepts and evaluation methods from research on criteria.

- Human rights and their inclusion in the technical standards of design.

- Working to increase the green areas as much as possible, as it is the lung of the prison building, which is a major factor for natural ventilation and lighting. It also works to convert carbon dioxide into oxygen through photosynthesis. 


\section{References:}

]$^{1}[$ Jewkes, Y., \& Johnston, H. (2012). The evolution of prison architecture. In Handbook on prisons (pp. 204-226): Routledge

]$^{2}[$ Moran, D., \& Jewkes, Y. (2015). Linking the carceral and the punitive state: A review of research on prison architecture, design, technology, and the lived experience of carceral space. Paper presented at the Annales de géographie.

[3] Dikötter, F. (2018). Cultures of confinement: a history of the prison in Africa, Asia, and Latin America: Cornell University Press

]$^{4}[$ Cunningham, E., et al. (2017). Ongoing incident hepatitis $C$ virus infection among people with a history of injecting drug use in an Australian prison setting, 2005-2014: The HITS-p study. 24(9), 733-741

5 [ ] McConville, S. (2015). A history of English prison administration: Routledge.

]$^{6}[$ Elizabeth Grant, Peter Hobbs. "West Kimberley Regional Prison". Architecture Media Pty Ltd. Retrieved 11 December 2013.

${ }^{7}$ [ ]New York Architects select prestigious international architecture awards for 2013, International Architecture Awards. The Chicago Athenaeum. 10 August 2013.

]$^{8}[$ Ibid

${ }^{9}$ [ ] National Architecture Awards: David Oppenheim Award' Architecture Australia,

$102(6)$

]$^{10}[$ Ibid

]$^{11}[$ Ibid

]$^{12}$ [ National Architecture Awards: David Oppenheim Award' Architecture Australia, $102(6)$

]$^{13}[$ Ibid

]$^{14}[$ Ibid

]$^{15}[$ Ibid

]$^{16}$ [UN General Assembly. Interim Report of the Special Rapporteur of the Human Rights Council on torture and other cruel, inhuman or degrading treatment or punishment. 2011. A/66/268,21.

- The International Committee of the Red Cross (ICRC) is a private humanitarian institution.

- $\underline{\text { IBC: }}$ International Building Code 